\title{
Serum acid phosphatase activities in patients with lung cancer: a biochemical and immunohistochemical analysis of 25 cases
}

\author{
G MORTIMER, * M CASEY
}

\section{From the Department of Histopathology, Mater Misericordiae Hospital, Dublin 7, Eire}

SUMMARY A series of 25 cases of lung cancer are presented in which total (TAcP) and nonprostatic serum acid phosphatase (NPAcP) activities were measured. Of these cases, $36 \%$ had raised TAcP and NPAcP activities in their serum. However, the serum activities of TAcP and NPAcP did not correlate with either the presence of lung cancer nor with the morphological tumour type. This fact indicates that, despite isolated reports of raised serum acid phosphatase activities in cases of lung cancer, acid phosphatase is of no value as a marker for lung cancer. We sought alternative explanations for the raised TAcP and NPAcP activities observed in our series in the hope that this enzyme might prove useful as a marker for early metastatic disease in lung cancer patients. This possibility is not substantiated, and the findings are analysed and discussed. It is tentatively suggested that raised NPAcP activities in patients with lung cancer may relate to haemostasis.

Acid phosphatase is a lysozomal enzyme ${ }^{1}$ of molecular weight 13400 to greater than $200000 .^{2}$ Acid phosphatase activity is demonstrable in various tissues, especially prostate where this knowledge is applied in the diagnosis of metastatic carcinoma of prostatic origin. Other tissues rich in acid phosphatase include liver, ${ }^{2}$ platelets, ${ }^{3}$ bone and red blood cells, ${ }^{4}$ and mammary epithelium. ${ }^{1}$ Apart from prostatic malignancy, other conditions may have associated increased activities of serum acid phosphatase including thrombocythaemia, ${ }^{35}$ multiple myeloma and metastatic pancreatic carcinoma, ${ }^{5}$ Gaucher's disease, ${ }^{56}{ }^{6}$ leukaemia, Paget's disease, renal disease and liver disease, ${ }^{6}$ and carcinoid tumour of rectum. ${ }^{7}$ Raised serum acid phosphatase has also been reported in bronchogenic carcinoma. ${ }^{8}$ Our index case, which was erroneously diagnosed as metastatic carcinoma of prostate mainly on the basis of raised TAcP activities, proved at necropsy to be a case of widely disseminated bronchogenic oat cell carcinoma with only benign hyperplastic changes in the prostate gland. This finding prompted us to explore the significance of serum acid phosphatase activities in patients with lung cancer. Twenty-five cases are presented and analysed biochemically and immuno-

*Present address: Department of Pathology, Royal Infirmary, Glasgow G4 0SF.

Accepted for publication 11 March 1981 histochemically. These include our index case (No 11 in this series) and all were studied with emphasis on tumour morphology, liver function, bone metab olism, platelet count, and haemolysis.

\section{Material and methods}

Twenty-five consecutive cases of lung cancer were studied. They were all newly diagnosed cases and all had full routine investigations including full blood count, urea and electrolytes, urinalysis, chest $x$-ray examination, and sputum cytology.

Diagnosis of lung cancer was obtained by various means including sputum cytology, bronchial biopsy, open lung biopsy, lymph node biopsy, $x$-ray, necropsy and pneumonectomy. One patient had lung cancer but precise diagnosis was not obtained (case 15).

\section{SERUM ACID PHOSPHATASE}

As soon as a diagnosis was established, blood was obtained by venepuncture into a dry $10 \mathrm{ml}$ tube, was immediately centrifuged, and the serum then removed and buffered with $5 M$ acetate buffer at pH 5.3 (20 microlitres per $\mathrm{ml}$ of serum) and frozen at $-20^{\circ} \mathrm{C}$ for later analysis for acid phosphatase. Acid phosphatase was assayed in serum samples in our biochemistry department with the method of Andersch and Szczypinski, ${ }^{9}$ and employing tartratestability test. 


\section{TISSUES}

Histological diagnosis was made by routine haematoxylin and eosin staining of formalin-fixed, paraffinembedded tissue sections.

Immunohistochemistry of tumours was performed on sections from these same paraffin-embedded blocks in 15 cases. This was carried out by means of the indirect immunoperoxidase technique with acid phosphatase antiserum donated by Dr A Leatham of Ludwig Cancer Institute, Royal Marsden Hospital, London. This antiserum was raised in rabbits by injection of acid phosphatase purified from pooled human semen. Normal postmortem prostate was used as a control in this series. The conjugates were obtained commercially, and two runs were carried out. The first run used swine antirabbit IgG conjugated with horseradish peroxidase (Dako) and the second run employed alkaline phosphatase-conjugated goat antirabbit IgG obtained from Miles-yeda. Tissue was not available for study of 10 of our cases.

\section{LIVER}

Liver function tests included serum bilirubin, transaminases (SGOT and SGPT), alkaline phosphatase (including electrophoresis on cellulose acetate for identification of isoenzymes in patients with raised enzyme activities in their serum), and serum protein (total, albumin, and globulin).

\section{RED CELLS}

Haemolysis was excluded clinically and by measurement of serum bilirubin and potassium.

\section{BONE}

Bone metabolism was assessed biochemically by measurement of serum calcium and phosphate.

\section{PLATELETS}

Platelet counts were performed in the routine way in our haematology department with a standard counting chamber.

\section{Results}

The results of this study are shown in Tables $1 \& 2$.

The series includes 25 patients, 18 men and seven women. Their ages ranged from 33 to $86 \mathrm{yr}$, mean $62.7 \mathrm{yr}$. The diagnosis in the series included oat-cell carcinoma, 12 cases $(48 \%$ ); epidermoid (squamous) carcinoma, 6 cases $(24 \%)$; fibrosarcoma and undesignated sarcoma, 2 cases $(8 \%)$; mesothelioma, 1 case $(4 \%)$; metastatic tumour, 1 case $(4 \%)$; and indeterminate morphological type, 3 cases $(12 \%)$.

SERUM ACID PHOSPHATASE

Serum acid phosphatase (AcP) activity was measured in all 25 cases. The total serum acid phosphatase activity (TAcP) was the only estimation in five cases, otherwise both TAcP and the NPAcP fraction (tartrate-stable) were measured. The five cases in which TAcP alone was measured each gave results within the normal reference range. Nine of the remaining 16 cases ( $36 \%$ of total number studied) had raised TAcP values. Of these nine cases, all AcP activities were mostly tartrate-stable (NPAcP). Five of the cases were oat-cell carcinomas $(56 \%)$, two were epidermoid carcinomas $(22 \%)$, one was a primary lung sarcoma $(11 \%)$, and one was a metastatic tumour of undetermined origin $(11 \%)$. Because of the small numbers involved, statistical analysis of these figures was not carried out. It is apparent, however, that raised serum NPAcP activity does not correlate with tumour morphology. It is also noteworthy that three of the nine patients with raised serum NPAcP were women (see Table 1 ).

\section{TISSUE SECTIONS}

Tissue sections from 15 cases were stained for AcP by the indirect immunoperoxidase technique. All 15 available tumours were negative in the first run and this finding was confirmed in the second run. The control tissues stained positively in each run, thereby confirming activity of the antiserum. Suitability of the antiserum was confirmed by positive staining of red blood cells and macrophages in the tumour sections. These findings were interpreted as indicating that the tumour cells themselves were not the source of the raised serum AcP observed. Seven further cases studied by immunohistochemistry did not contain any tumour tissue when the blocks were cut. There was no tissue available for study from three cases (Nos 15, 16, and 17 in the Tables). Of the other cases from which tumour tissue was not available in the blocks for immunohistochemistry, cases 4 and 5 had raised serum activities of NPAcP. This reduced the number of cases with raised serum NPAcP studied histochemically to seven. The remainder of this study was devoted to correlation of raised serum NPAcP in lung cancer patients with tests of function of other tissues (see Tables 1\&2).

\section{LIVER}

Liver function tests were carried out in all 25 cases in this study. Of the nine cases with raised serum NPAcP activities, complete liver function tests were available in five, but abnormalities were apparent in all nine cases $(100 \%)$. These ranged from minor disturbances of individual parameters to severe upset in the full range of tests. However, similar degrees of abnormality were noted in 14 of the 16 cases with normal serum NPAcP or TAcP activities $(87 \%)$ or both. The single case with grossly abnormal liver 
function tests is the index case (No 11 in Table 2) in which metastases were demonstrated in liver, bones, brain, marrow, spleen, and kidneys, and in which abnormalities of bone metabolism were also demonstrated (vide infra). Of particular note is the fact that the level of serum NPAcP activity does not correlate with any single parameter or group of parameters of liver function in the entire series.

Isoenzymes of alkaline phosphatase were studied in seven of eight cases in which raised serum alkaline phosphatase was noted during assessment of liver function. (Index case serum was not available for this examination.) All seven cases revealed liver isoenzyme with a trace of bone isoenzyme in one case (this case had normal indices of bone metabolism). These findings do not parallel the serum NPAcP activity in the respective patients and thus fail to support the concept of liver as the source of the raised serum NPAcP. Neither do these tests correlate with tests of bone metabolism.

The possibility that liver dysfunction may precede a rise in serum NPAcP in cases of hepatic metastases was considered but rejected, as the activity of serum alkaline phosphatase fails to correlate with or parallel its AcP counterpart. (See Table 2.)

BONE

Serum calcium and phosphate concentrations were used as indices of bone metabolism and were measured in 24 of the 25 cases in this study. Abnormalities were observed in four cases $(17 \%)$. These were associated with raised serum activities of NPAcP in two cases, but did not correlate with the AcP activities in the other six cases in which calcium and phosphate concentrations were also measured, and further, abnormal calcium and phosphate concentrations were noted in two cases with normal serum activities of AcP. Neither did the serum concentrations of calcium and phosphate correlate with alkaline phosphatase activities (see Tables 1\&2).

\section{HAEMOLYSIS}

None of the cases in this study showed any clinical evidence of haemolysis. Serum potassium was marginally raised in two cases but each of these had normal serum TAcP activities. The serum bilirubin concentration was raised in one of these two cases but this was accompanied by raised serum transaminases and was attributed to liver dysfunction rather than haemolysis (see Tables).

\section{PLATELETS}

Platelet counts were available in nine cases. Four of these showed raised platelet counts and two of these $(50 \%)$ were associated with raised serum activities of TAcP and NPACP, one in a female patient and one in

Table 1 (Reference values given in parentheses)

\begin{tabular}{|c|c|c|c|c|c|c|c|c|c|c|}
\hline \multirow[t]{2}{*}{ Case No and type } & \multirow[t]{2}{*}{ Age } & \multirow[t]{2}{*}{ Sex } & \multicolumn{2}{|c|}{ Acid phosphatase (serum) } & \multicolumn{2}{|c|}{ *Immunohistochemistry } & \multicolumn{2}{|c|}{ Haemolysis } & \multicolumn{2}{|c|}{ Bone metabolism } \\
\hline & & & $\begin{array}{l}\text { Total } \\
(0-9 \text { IU } / l)\end{array}$ & $\begin{array}{l}\text { Non- } \\
\text { prostatic }\end{array}$ & $\begin{array}{l}\text { Alkaline } \\
\text { phosphatase }\end{array}$ & $\begin{array}{l}\text { Horseradish } \\
\text { peroxidase }\end{array}$ & $\begin{array}{l}\text { Seru } \\
(3 \cdot 6-\end{array}$ & $\begin{array}{l}m \text { potassium } \\
5.0 \mathrm{mmol}(E q) / l)\end{array}$ & $\begin{array}{l}\text { Serum } \\
\text { calcium } \\
(2 \cdot 20-2 \cdot 63 \\
\text { mmol } / \mathrm{l})\end{array}$ & $\begin{array}{l}\text { Serum } \\
\text { phosphate } \\
(0.65-1.62 \\
\text { mmolll })\end{array}$ \\
\hline 1 Oat cell & 73 & $\mathbf{M}$ & $8 \cdot 4$ & - & - & - & Nil & $4 \cdot 4$ & $2 \cdot 65$ & $1 \cdot 32$ \\
\hline 2 Oat cell & 52 & $\mathbf{M}$ & $6 \cdot 3$ & - & - & - & Nil & $3 \cdot 5$ & $2 \cdot 60$ & $1 \cdot 10$ \\
\hline 3 Oat cell & 37 & $\mathbf{M}$ & $5 \cdot 2$ & $3 \cdot 8$ & No tissue & & Nil & $4 \cdot 7$ & $2 \cdot 50$ & $1 \cdot 07$ \\
\hline 4 Oat cell & 57 & $\mathbf{F}$ & $13 \cdot 8$ & $10 \cdot 7$ & No tissue & & Nil & $4 \cdot 8$ & 3.00 & 1.03 \\
\hline 5 Oat cell & 63 & $\mathbf{F}$ & $17 \cdot 5$ & $16 \cdot 9$ & No tissue & & Nil & $3 \cdot 9$ & $2 \cdot 35$ & $1 \cdot 39$ \\
\hline 6 Oat cell & 52 & $\mathbf{M}$ & $32 \cdot 1$ & $30 \cdot 3$ & - & - & Nil & $4 \cdot 0$ & $2 \cdot 40$ & 0.94 \\
\hline 7 Oat cell & 86 & $\mathbf{F}$ & $8 \cdot 9$ & $8 \cdot 3$ & No tissue & & Nil & $3 \cdot 3$ & $2 \cdot 35$ & $1 \cdot 07$ \\
\hline 8 Oat cell & 61 & $\mathbf{M}$ & $9 \cdot 8$ & $9 \cdot 7$ & 一 & 一 & - & & - & $\rightarrow$ \\
\hline 9 Oat cell & 64 & $\mathbf{M}$ & $7 \cdot 6$ & $7 \cdot 5$ & 一 & - & Nil & $4 \cdot 2$ & $2 \cdot 25$ & $1 \cdot 29$ \\
\hline 10 Oat cell & 71 & $\mathbf{F}$ & $6 \cdot 0$ & $3 \cdot 8$ & - & - & Nil & $4 \cdot 1$ & $2 \cdot 57$ & 0.93 \\
\hline 11 Oat cell & 73 & $\mathbf{M}$ & $11 \cdot 7$ & $9 \cdot 6$ & - & - & Nil & $4 \cdot 5$ & 3.00 & $1 \cdot 36$ \\
\hline 12 Oat cell & 70 & $\mathbf{M}$ & $7 \cdot 4$ & $5 \cdot 9$ & No tissue & & Nil & $4 \cdot 4$ & $2 \cdot 18$ & 1.03 \\
\hline 13 Metastasis & 73 & $\mathbf{M}$ & $18 \cdot 9$ & $14 \cdot 7$ & - & - & Nil & $4 \cdot 4$ & $2 \cdot 33$ & $1 \cdot 20$ \\
\hline 14 Sarcoma & 69 & $\mathbf{M}$ & $11 \cdot 0$ & $8 \cdot 3$ & $-\pi$ & - & Nil & $4 \cdot 8$ & $2 \cdot 15$ & 0.87 \\
\hline 15 Not defined & 67 & $\mathbf{M}$ & $2 \cdot 8$ & 0 & No tissue & & Nil & $3 \cdot 9$ & $2 \cdot 35$ & $1 \cdot 20$ \\
\hline 16 Not defined & 73 & $\mathbf{M}$ & $8 \cdot 5$ & $6 \cdot 2$ & No tissue & & Nil & $4 \cdot 1$ & $2 \cdot 30$ & $1 \cdot 00$ \\
\hline 17 Not defined & 73 & $\mathbf{F}$ & $4 \cdot 9$ & $2 \cdot 6$ & No tissue & & Nil & 3.9 & $2 \cdot 20$ & $1 \cdot 07$ \\
\hline 18 Fibrosarcoma & 62 & $\mathbf{M}$ & $5 \cdot 8$ & - & - & - & Nil & $4 \cdot 6$ & $2 \cdot 30$ & 0.90 \\
\hline 19 Mesothelioma & 33 & $\mathbf{M}$ & $4 \cdot 2$ & - & No tissue & & Nil & $4 \cdot 6$ & $2 \cdot 40$ & $1 \cdot 03$ \\
\hline 20 Epidermoid & 63 & $\mathbf{M}$ & $7 \cdot 7$ & $6 \cdot 7$ & - & - & Nil & $4 \cdot 0$ & $3 \cdot 13$ & $1 \cdot 03$ \\
\hline 21 Epidermoid & 66 & $\mathbf{M}$ & $7 \cdot 8$ & 6.9 & - & - & Nil & $3 \cdot 9$ & $2 \cdot 35$ & $1 \cdot 03$ \\
\hline 22 Epidermoid & 53 & $\mathbf{F}$ & $10 \cdot 2$ & $8 \cdot 3$ & - & 一 & Nil & $3 \cdot 9$ & $2 \cdot 23$ & $1 \cdot 29$ \\
\hline 23 Epidermoid & 74 & $\mathbf{F}$ & $8 \cdot \overline{3}$ & $7 \cdot 5$ & No tissue & & $?$ & $5 \cdot 7$ & $2 \cdot 40$ & $\mathbf{1} \cdot \mathbf{2 3}$ \\
\hline 24 Epidermoid & 44 & $\mathbf{M}$ & $14 \cdot 0$ & $11 \cdot 6$ & - & - & Nil & $4 \cdot 0$ & $2 \cdot 38$ & 0.84 \\
\hline 25 Epidermoid & 58 & $\mathbf{M}$ & $3 \cdot 5$ & - & - & - & $?$ & $5 \cdot 2$ & $2 \cdot 50$ & 0.74 \\
\hline
\end{tabular}

*Immunohistochemistry: - = negative. Conversion: SI to traditional units Calcium $1 \mathrm{mmol} / 1 \approx 4.0 \mathrm{mg} / 100 \mathrm{ml}$. Phosphate $1 \mathrm{mmol} / 1 \approx 3.1 \mathrm{mg} / 100 \mathrm{ml}$. 
Table 2

\begin{tabular}{|c|c|c|c|c|c|c|c|c|}
\hline \multirow[t]{2}{*}{ Case No and type } & \multirow{2}{*}{$\begin{array}{l}\text { Platelets } \\
(150-400 \\
\left.\times 10^{\circ} / l\right)\end{array}$} & \multirow{2}{*}{$\begin{array}{l}\text { Bilirubin } \\
(0-14 \\
\mu \mathrm{mol} / l)\end{array}$} & \multirow{2}{*}{$\begin{array}{l}\text { SGOT } \\
(8-40 \\
I U / l)\end{array}$} & \multirow{2}{*}{$\begin{array}{l}\text { SGPT } \\
(5-35 \\
I U / I)\end{array}$} & \multirow{2}{*}{$\begin{array}{l}\text { Alkaline phosphatase isoenzyme } \\
\text { level } \\
(35-150 \\
I U / I)\end{array}$} & \multicolumn{3}{|l|}{ Proteins } \\
\hline & & & & & & $\begin{array}{l}\text { Total } \\
(58-80 \mathrm{~g} / \mathrm{l})\end{array}$ & $\begin{array}{l}\text { Albumin } \\
(35-53 \mathrm{~g} / \mathrm{l})\end{array}$ & $\begin{array}{l}\text { Globulin } \\
(18-36 \mathrm{~g} / \mathrm{I})\end{array}$ \\
\hline 1 Oat cell & - & 10 & - & - & 60 & 81 & 41 & 40 \\
\hline 2 Oat cell & 253 & 5 & 22 & 14 & 94 & 78 & 39 & 39 \\
\hline 3 Oat cell & 570 & 5 & 25 & 36 & 60 & 76 & 36 & 40 \\
\hline 4 Oat cell & - & 9 & - & - & $179 \ldots \ldots$ Liver & 71 & 39 & 32 \\
\hline 5 Oat cell & 424 & 10 & 41 & 26 & 77 & 70 & 40 & 32 \\
\hline 6 Oat cell & - & 9 & 21 & 17 & 81 & 83 & 41 & 42 \\
\hline 7 Oat cell & - & 9 & 17 & 18 & 112 & 63 & 38 & 25 \\
\hline 8 Oat cell & - & - & - & - & 112 & - & - & - \\
\hline 9 Oat cell & - & 15 & 28 & 18 & 69 & 72 & 35 & 37 \\
\hline 10 Oat cell & 282 & 8 & - & - & 67 & 72 & 36 & 36 \\
\hline 11 Oat cell & - & 46 & 200 & 200 & $>1000$ & 65 & 29 & 36 \\
\hline 12 Oat cell & 393 & 5 & - & - & 105 & 65 & 31 & 34 \\
\hline 13 Metastasis & - & 5 & 27 & 26 & $297 \ldots$. . Liver + bone & 71 & 32 & 39 \\
\hline 14 Sarcoma & - & 10 & - & - & $261 \ldots \ldots$ Liver & 65 & 23 & 42 \\
\hline 15 Not defined & - & 7 & - & - & 130 & 72 & 35 & 37 \\
\hline 16 Not defined & - & 12 & - & - & $157 \ldots \ldots$ Liver & 76 & 37 & 39 \\
\hline 17 Not defined & 545 & 10 & 15 & 22 & 91 & 69 & 31 & 38 \\
\hline 18 Fibrosarcoma & 260 & 24 & 40 & 27 & 103 & 64 & 34 & 30 \\
\hline 19 Mesothelioma & - & 7 & 23 & 34 & 100 & 75 & 41 & 34 \\
\hline 20 Epidermoid & - & 10 & - & - & 102 & 75 & 34 & 41 \\
\hline 21 Epidermoid & - & 10 & 20 & 19 & $159 \ldots \ldots$ Liver & 75 & 36 & 39 \\
\hline 22 Epidermoid & - & 5 & - & - & $153 \ldots \ldots$ Liver & 68 & 31 & 37 \\
\hline 23 Epidermoid & - & 9 & - & 一 & $153 \ldots .$. Liver & 68 & 25 & 43 \\
\hline 24 Epidermoid & 470 & 5 & 23 & 18 & 52 & 76 & 39 & 37 \\
\hline 25 Epidermoid & 181 & 65 & 45 & 36 & 62 & 69 & 35 & 34 \\
\hline
\end{tabular}

Conversion: SI to traditional units Bilirubin $1 \mu \mathrm{mol} / 1 \approx 0.0585 \mathrm{mg} / 100 \mathrm{ml}$.

a male. All of these four cases were shown to have normal indices of bone metabolism, normal serum potassium, normal serum bilirubin in three, and virtually normal liver function tests. As the serum alkaline phosphatase was also normal in the case with slightly raised serum bilirubin, it is unlikely that the raised serum NPAcP activity here is emanating from the liver. Therefore, some correlation seems to exist between the blood platelet count and serum NPAcP activity (see Tables $1 \& 2$ ).

\section{Discussion}

Serum AcP activities in patients with lung cancer became of great importance to us because of an erroneous diagnosis of metastatic cancer of prostate in a man with raised serum AcP who was shown at necropsy to have disseminated bronchial oat-cell carcinoma.

Raised activities in serum AcP have been recorded previously in isolated cases of lung cancer, as well as in other malignancies especially prostatic cancer, as mentioned earlier (vide supra). We decided to test the possible association between lung cancer and serum AcP activity.

This series of 25 cases of lung cancer revealed nine cases with raised serum NPAcP activity (36\% incidence). Of these, $56 \%$ were associated with oat-cell carcinoma, but raised activities were also noted in cases of epidermoid carcinoma, metastatic carcinoma, sarcomatous and mesotheliomatous neoplasms. This raised NPAcP activity in serum was observed in three female patients $(33 \%)$. Immunohistochemical study failed to demonstrate AcP in any of the tumours available for study. Consequently, it is clear that, despite the high incidence of raised serum NPAcP in lung cancer patients, this NPAcP does not originate in the tumours themselves, nor does the raised serum activity of NPAcP correlate with tumour morphology but may be observed in any type of lung tumour, even metastatic tumour. In addition seven of the nine lung cancer cases have biochemical evidence of dysfunction of liver or bone metabolism or both. Case No. 8 has incomplete tests of liver function, and case No. 24 is one with a raised platelet count (vide-infra), so that eight of the nine cases with raised serum AcP offer immediate alternative explanations other than tumour product.

Other tissues known to contain AcP (apart from prostate) include liver, bone, red blood cells, and platelets. It was attempted, on the basis of this knowledge, to correlate the observed raised serum activities of NPAcP in our nine patients with biochemical evidence of dysfunction of these tissues. However, no clear association could be found between liver dysfunction, haemolysis or bone metabolism and raised serum NPAcP activity. Therefore, serum NPAcP activity cannot be held to reflect the possible pre- 
sence of tumour metastases in these organs (liver or bone). It was considered that raised serum alkaline phosphatase activity might indicate hepatic metastasis of lung cancer, but even if this assumption were correct, then from our study it would clearly have to precede any rise in serum NPAcP and so invalidate the latter as a screening test for early hepatic metastasis.

One aside noted was the association of raised serum NPAcP activities in two of four patients with raised platelet counts. The numbers involved here are too small to allow conclusions to be drawn, but if this association were confirmed in a larger series, it could add to our knowledge of thrombosis and embolism in patients with malignant disease.

The main points to emerge from this series, however, are

(1) despite individual case reports, raised serum acid phosphatase activities are of no value as a marker of lung cancer and the state of biochemical markers of lung cancer remains as recently reviewed $;{ }^{10}$

(2) Serum acid phosphatase activities do not reflect the presence or absence of distant metastases of lung cancer, and are of no value as a screening device for early detection of metastases.

\section{References}

${ }^{1}$ Livni N, Laufer A. Histochemical studies of human breast tumours: activity of alkaline phosphatase, acid phosphatase, and glucose-6-phosphate dehydrogenase. Path Microbiol 1975;42:159-70.

${ }^{2}$ Rehkop DM, Van Etten RL. Human liver acid phosphatases. Hoppe Seylers Z Physiol Chem 1975;356:177582.

${ }^{3}$ Tavassoli M, Yelenosky R. Platelet-derived acid phosphatase isoenzyme in the serum in thrombocythaemia. Am J Clin Pathol 1977;67:177-9.

' Zilva JF, Pannall PR. In: MacLagan NF, ed. Clinical chemistry in diagnosis and treatment London: LloydLuke, $1975: 351-2$.

'Mick BA. Abnormally high serum acid phosphatase. JAMA 1972;220:1132.

${ }^{6}$ Mercer DW. Separation of tissue and serum acid phosphatase isoenzymes by ion-exchange column chromatography. Clin Chem 1977;23:653-8.

'Davidson ED, McDougal WS. Elevated serum acid phosphatase levels with rectal carcinoid tumour. Gastroenterology 1976;70:114-6.

${ }^{8}$ Nicholls DP, Davies JS. Acid phosphatase activity in carcinoma of the bronchus. Thorax 1977;32:472-7.

${ }^{9}$ Andersch MA, Szczypinski AJ. Use of $p$-nitrophenylphosphate as the subtrate in determination of serum acid phosphatase. Am J Clin Pathol 1947;17:571. Cited by Tannenbaum M. Urologic pathology: the prostate. Philadelphia: Lea and Febiger, 1977.

${ }^{10}$ Coombes RC, Ellison MD, Neville AM. Biochemical markers in bronchogenic carcinoma. BrJ Dis Chest 1978; $72: 263-87$

Requests for reprints to: Dr G Mortimer, Department of Pathology, Royal Infirmary, Glasgow G4 OSF, Scotland. 